\title{
Effect of Perfectionistic and Brand Conscious on Consumer Decision-making Style of Young Adult in Batam in Mobile Phone Purchase
}

\author{
Realize, Tukino, Emil Eka Putra
}

\begin{abstract}
Mobile phone business competition moves faster and more complex. This situation forces mobile phone manufacturers to be more creative and innovative in creating new products. Perfectionistic difference is one of the reasons consumers are willing to pay more for a brand of mobile phone products that are considered quality product. Marketing activities play a role in consumer purchasing decisions in addition to customer confidence in a product so that confidence arises in the purchasing actions taken. This research is quantitative research, a type of research with the characteristics of the problem in the form of influence relations. This study uses perfectionistic, and brand conscious as an independent variable and consumer decision-making style as a dependent variable. This study is aimed to look at the regression relationship between perfectionistic and brand conscious variable and the consumer decision making style of the young adults in Batam in purchasing mobile phone products. 393 private college students in Batam were taken as respondents by using proporsive sampling technique. The results of data analysis and hypothesis testing showed that Perfectionistic significantly influenced Consumer Decision-making Style, Brand Conscious had an influence on Consumer Decision-making Style and Perfectionistic and Brand Conscious simultaneously influenced Consumer Decision-making Style.
\end{abstract}

Keywords: Perfectionistic, Brand Conscious, Decision-Making Style, Young Adult

\section{INTRODUCTION}

Increasingly fierce, diverse, and very volatile business competition forces business owners to innovate and develop creatively and intuitively so that they can create superior products which will certainly be different from the products of the competitor and become a characteristic of the products produced by their company. Consumers expect the company not only to be able to improve product quality but also to be

\footnotetext{
Revised Manuscript Received on September 22, 2019.

* Correspondence Author

Realize*, Doctor of economics by concentrating in marketing. Currently she is a lecturer and as chairman of the quality assurance center at Putera Batam University, Batam - Kepulauan Riau, Indonesia. She can be reached through realize.eel@gmail.com or realize@puterabatam.ac.id

Tukino, Master of Information System Management, STMIK Putera Batam, Certified Cisco CCNA Instructor from Electrical Engineering and Information Technology Department, Gadjah Mada University 2016. Currently he is a lecturer of Computer Science at Putera Batam University, Batam - Kepulauan Riau, Indonesia. He can be reached through tukino@puterabatam.ac.id.

Emil Eka Putra, Master of Arts concentrating on Contemporary Literature. He is currently a lecturer of English Department of Putera Batam University, Batam - Kepulauan Riau, Indonesia. He can be reached through emil.eka@puterabatam.ac.id.
}

able to offer very affordable product prices. The role of marketing is also important. Companies require promotion facilities that enable them to communicate very well with consumers so that they are able to influence and force consumers to make decisions to buy products or services offered. In addition, in terms of distribution of products or services companies should guarantee that their products can be easily found and obtained by consumers.

Trust and confidence in a product or service are determining factors that determine when consumers decide to buy a product or service. This arises due to the success of the company in influencing consumer purchasing decisions, so that a sense of victory, satisfaction and justification of attitudes towards the decision to buy the product will emerge. In consumer behavior it has been stated that there are very many factors that can contribute to consumer buying decisions, such as product prices, product brands, promotions and others. Factors that influence the decision of consumers to buy a product can arise from the consumers themselves or come from other parties who are able to influence prospective customers [1].

Nowadays, information about products or services is much easier and faster accessed by consumers so that it is not easy to gain consumer trust without being accompanied by proof of the promotion that has been done. In fact, some companies are forced to follow the wishes of consumers to gain trust in the brands of products they have. Consumer trust will only be understood as a source of competitive advantage when the belief is understood as behavior or real action [2] and consumer trust will be one of the capital in competitive advantage [3].

Batam in Kepulauan Riau province, is one of the large cities with the third largest population in the western part of Indonesia after Medan and Palembang. In the early period of Batam in the 1970s, there were only around 6,000 people living in the city. However, in 2017, the data published by the Batam Central Bureau of Statistics (BPS) showed that there was a significant increase in the number of population of the city to $1,236,399$ people. Batam's strategic location, namely in the position of shipping and international trade lines and directly adjacent to Malaysia and Singapore, has caused the industry to grow rapidly, including the education industry. Based on information obtained from the Higher Education Data Base of the Directorate General of Higher Education, the Ministry of Research, Technology and Higher Education (PDPT Directorate General of Kemenristekdikti) 
there are 21 higher education institutions in Batam. One of these 21 institutions is state college namely Batam State Polytechnic while 20 others are private college, namely:

1. 5 Academies, namely the Accounting Academy of Permata Harapan Batam, Putra Jaya Batam Health Analyst Academy, Permata Harapan Foreign Language Academy, Putra Jaya Mandiri Midwifery Academy Batam, Batam Tourism Polytechnic

2. 10 High Schools, namely STIE Bentara Persada Batam, STIE Galileo, STIE Ibnu Sina, STIE Nagoya Indonesia, STIKES Ibnu Sina Batam, STIKES Awal Bros Batam, STIKES Mitra Bunda Persada, Muhammadiyah College of Computer Science Batam, STMIK GICI, STT Ibn Sina

3. Universities, namely Putera Batam University, Batam International University, Riau Kepulauan University, Batam University and Universal University.

Batam as a city with a very rapid rate of economic growth both at the provincial level and at the national level has its own uniqueness. This very rapid economic growth rate is one of the triggers for high consumer attitudes and purchasing power, especially among the youth. Cellular phones are one of the products that are always in demand and become a social icon of the Batam youth. Technological facilities offered by cellular telephones have changed the lifestyle of Batam youth both in the society and in their work environment. It even creates its own communication identity for the owner. Various brands of cellular telephones with all of their outstanding specifications and facilities are offered. Brand familiarity and the availability of feature facilities are the determinants of cellular phones prices.

The mobility of the cellular telephone industry is experiencing remarkable progress. The very diverse prices of cellular telephones have caused almost all levels of society to have cellphones. At present mobile phones are not only used as a means of voice communication, but have become highly reliable equipment both in terms of their usefulness and as a means of indicating prestige and lifestyle. Rapid technological advancements participated in improving its function. Some supporting technological capabilities have been integrated into cellular telephone products such as the dual sim cards technology, radio, camera, internet access capability and remote control device. Besides that manufacturers also try to provide attractive appearance both in terms of size and shape of the product.

Young people in Batam are divided into 3 categories, namely those who are focusing on working for their lives, those who are focusing on continuing their education at one of the universities in Batam, and the last category is those who are continuing their studies by studying at one of the universities in Batam while working. This last category is the most dominant category. Based on observations conducted in the field, it was found that they tend to use cellular phones for various purposes such as means of communication, seeking information and literature, access at work and on campus, and entertainment. Those above mentioned phenomena are the the basis of the author in conducting this research which want to measure whether Perfectionistic and Brand Conscious have a positive contribution to Consumer Decision making Style for students in buying cellular phones.

\section{LITERATURE REVIEW}

In general, consumers have a certain orientation in the shopping decision making style [4]. Consumer decision-making style can be said as a description of consumer behavior in the decision making process to obtain products or services that are in accordance with the standards of their needs [5]. The concept of Consumer Decision Making Style is divided into 2 categories, namely (1) consumers buy certain brand products because they only require a little effort to get the products, but they will move to another brand when they no longer get convenience and comfort, and (2) Consumers which reflects the consciousness of always buying particular brand products, and this is based on the high commitment of consumers to these brands [6].

This commitment of consumer plays a very important role in Decision making Style [7] and [8]. Consumer decision-making styles can be used as a basis for grouping consumers into different segments [9]. Consumer Decision Making Style has a very positive impact on the company, because it will ease the company to serve the desires of consumers and consumers will be willing to pay a high price to get the product [10]. Even without realizing it, consumers indirectly will become embasador of the company's products.

Perfectionistic is a characteristic or behavior shown by consumers when shopping, where they always pay attention to and prioritize the best quality of a product [11]. This opinion is strengthen by the opinion that Perfectionistic is a characteristic of evaluating the attitudes of consumers who carefully get the highest quality products [9].

Their confidence and trust in a product creates fanaticism towards certain brands that they believe to be superior and best products. Brand conscious become one of the measuring instruments for consumers tendency in shopping. This is created by a comparison of consumer expectations and desires for product quality with the reality that the producers offer [12] or in other words consumers' assessment of the superiority of a product [13]. The company's ability to fulfill consumer's expectations determines the assessment of the products they produce [14]. Although in the end consumers will get expensive prices for well-known brands [9]. They are willing to pay high to get the product. This is because of the satisfaction that consumers feel when having a quality product [15].

Consumers still believe that expensive prices are the indicator of the best quality products. In India, students living in urban areas are generally more brands conscious because they buy products to show prestige and lifestyle [16].

\section{METHODOLOGY}

The population in this study were students of 20 private colleges in Batam which totally of 23,815 students. The distribution of this population for each college is: Batam University 2,340 students, Batam International University 3,331 students, Riau Kepulauan University 5,467 students, Putera Batam University 6,186 students, Universal University 478 students, STIE Ibn Sina 1,406 students, STIE Bentara Persada Batam 216 students, STT Ibnu Sina 1,672 students, STIKES Ibnu Sina Batam 45 students , STIKES Awal Bros Batam 263 students, STIKES 
Mitra Bunda Persada 768 students, Muhammadiyah Computer Science College Batam 198 students, STIE Nagoya Indonesia 228 students, STMIK GICI 435 students, STIE Galileo 149 students, Putra Jaya Batam Academy of Health Analyst 92 students, Permata Harapan Academy of Foreign Languages 42 students, Permata Harapan Batam Academy of Accountancy 167 students, Putra Jaya Mandiri Midwifery Academy Batam 37 students, and Batam Tourism Polytechnic 295 students.

Slovin's formula with a set precision level of 5\% is applied in determining the number of samples used in this study. Samples were distributed using proportional sampling techniques for active students. The data used in this study is primary data which is a collection of questionnaire data filled in by a number of respondents according to the number of samples set [17].

\section{RESULT AND DISCUSSION}

If we look at the results of the respondents' questionnaires, the majority of private university students in Batam are not fresh graduates and have worked. The dominant category of income is of more than 4 million per month at $63.9 \%$. In general, they are private employees with $38.7 \%$ and entrepreneurship of $29.8 \%$.

The results of the data validity test for the Perfectionistic (X1) variable are X11 of $0.738, \mathrm{X} 12$ of $0.667, \mathrm{X} 13$ of 0.672 , $\mathrm{X} 14$ of 0.629 and X15 of 0.621 . While for Brand Conscious (X2) variable, that is X21 at $0.635, \mathrm{X} 22$ at $0.798, \mathrm{X} 23$ at $0.769, \mathrm{X} 24$ at $0.617, \mathrm{X} 25$ at 0.784 and $\mathrm{X} 26$ at 0.780 . Based on the results of this test, all data are valid because all test results proven to be greater than the $r$ table value which is 0.099 .

Based on the results of variable reliability testing, it is known that the Perfectionistic variable has a value of Cronbach's Alpha 0.852 while the Brand Conscious variable has a Cronbach's Alpha value of 0.901. Because Perfectionistic and Brand Conscious have a Cronbach's Alpha Value higher than the threshold value of 0.6 , this research instrument is considered reliable.

The Kolmogorov-Smirnov test result (K-S) shows that the data are normally distributed because of the level of significance that the Asymp value has. Sig. (2-tailed) is 0.913 which means it is greater than the threshold value of 0.05 .

The test results on multicollinearity variables indicate that the tolerance value of the Perfectionistic variable and the Brand Conscious variable is 0.613 , which means that the tolerance value of Perfectionistic and Brand Conscious is higher than 0.10. And the value of the Variance Inflation Factor (VIF) of Perfectionistic and Brand Conscious variable is 1.631. This VIF value is still below 10 which is the VIF value threshold. This means that between Perfectionistic variables and Brand Conscious variables there is no symptoms of multicollinearity.

The hypothesis testing in this study is done partially and simultaneously.

Table- 1: Partial Hypothesis Testing Result

\begin{tabular}{|c|l|c|c|}
\hline \multicolumn{2}{|l|}{ Model } & t & Sig. \\
\hline \multirow{2}{*}{1 (Constant) } & 2.661 & .014 \\
\cline { 2 - 4 } $\mathrm{X} 1$ & 3.417 & .002 \\
\hline \multicolumn{2}{|l}{$\mathrm{X} 2$} & 4.749 & .000 \\
\hline
\end{tabular}

Based on the test results in the table above, then:
1. The significance value of the Perfectionistic variable is 0.002 and the Brand Conscious variable is 0,000. which means less than the probability value of 0.005 .

2. The value of the Perfectionistic t variable is 3.417 and the Brand Conscious variable is 4.749 and this means higher than the t table value which is 1.966 .

So, it can be concluded that the hypothesis which states the causality relationship in the research model is acceptable.

Table- 2: Simultaneous Hypothesis Testing

\begin{tabular}{|l|c|c|}
\hline Model & F & Sig. \\
\hline Regression & 44.360 & $.000^{\mathrm{b}}$ \\
\hline Residual & & \\
\hline Total & & \\
\hline
\end{tabular}

The table shows the results of the $\mathrm{F}$ test, the regression analysis shows the significance value of 0,000 , which means less than the probability coefficient of 0.05 . This means that the hypothesis which states the causality relationship in the research model is acceptable.

Table- 3: Determination Coefficient

\begin{tabular}{|c|r|r|r|}
\hline Model & \multicolumn{1}{|c|}{ R } & \multicolumn{1}{|c|}{ R Square } & $\begin{array}{c}\text { Adjusted R } \\
\text { Square }\end{array}$ \\
\hline 1 & $.895^{\mathrm{a}}$ & .801 & $\mathbf{. 7 8 3}$ \\
\hline
\end{tabular}

The results of the coefficient of determination testing listed in the above table shows that the value of R Square is 0.801 or equal to $80.1 \%$. This value reflects that the Consumer Decision Making Style variable is influenced by the Perfectionistic and Brand Conscious variables of $80.1 \%$.

\section{CONCLUSION}

\section{Perfectionistic has a significant effect on Consumer Decision Making Style}

Perfectionistic variables have a t value higher than t table and a significance value lower than the probability value. This indicates that Perfectionistic partially influence the Consumer Decision Making Style of college students in Batam. Based on observations made in the field, around $53 \%$ of respondents stated that the quality of the products and the features offered were still their priorities in buying cellular phones. The findings of this study support the opinions which stated that Perfectionistic also determines consumer Decision Making Style in purchasing products [18]-[19].

\section{Brand Conscious has a significant effect on Consumer Decision Making Style}

Brand Conscious variables have a t-value higher than $\mathrm{t}$ table and a significance value lower than the probability value. This shows that Brand Conscious has an influence on Consumer Decision Making Style of Batam's college students. This is supported by government policies that establish Batam as one of the free trade zones. This further resulting in the proliferation of shops in Batam that sell cellular phones with various well-known brands ranging from official distributors to small counters that only sell certain types of cellphones. This finding is different from the results of a previous study which found that Jordanian college students were not brand conscious, but they still believed price as a barometer in making choices, if the price of the product was expensive then it could be ascertained that the quality of the product was also better [19]. On the other hand the result of this study is in line which stated that brand is one 
of the determining factors of consumers products purchase decision [11]-[20].

\section{Perfectionistic and Brand Conscious have a significant effect on Consumer Decision Making Style}

Based on the results of simultaneous hypothesis testing it is known that the results of the $F$ test with a value of $F$ are higher than the value of the $\mathrm{F}$ table and the significance value is smaller than the probability value. This shows that Perfectionistic and Brand Conscious simultaneously influence the Consumer Decision Making Style of students in Batam. The determination coefficient value shows that the Consumer Decision Making Style variable is influenced by the Perfectionistic and Brand Conscious variables of $80.1 \%$.

\section{REFERENCES}

[1] Kotler, P., Keller, K. L., Brady, M., Goodman, M., \& Hansen, T. (2016). Marketing management: Pearson Education Ltd.

[2] Caldwell, C., \& Hansen, M. H. (2010). Trustworthiness, governance, and wealth creation. Journal of Business Ethics, 97(2), 173-188.

[3] Brahmasari, I. A., \& Panjaitan, H. (2017). The Influence of Using Academic Information System on Private University Image and Its Impact to Competitive Advantage. Archives of Business Research, 5(8).

[4] Sproles, G. B. (1985). From perfectionism to fadism: Measuring consumers' decision-making styles. Paper presented at the Proceedings, American Council on Consumer Interests.

[5] Levy, S. J. (1999). Brands, consumers, symbols and research: Sidney J Levy on marketing: Sage.

[6] Dick, A. S., \& Basu, K. (1994). Customer loyalty: toward an integrated conceptual framework. Journal of the academy of marketing science, 22(2), 99-113

[7] Berné, C. (1997). Modelización de la poscompra: satisfacción y lealtad. El comportamiento del consumidor, 163-179.

[8] Luarn, P., \& Lin, H.-H. (2003). A Consumer Decision Making Style Model For E-Service Context. Journal of Electronic Commerce Research, 4(4), 156-167.

[9] Azizi, S., \& Makkizadeh, V. (2012). Consumer decision-making style: the case of Iranian young consumers. Journal of Management research, $4(2), 88$.

[10] Gee, R., Coates, G., \& Nicholson, M. (2008). Understanding and profitably managing customer loyalty. Marketing Intelligence \& Planning, 26(4), 359-374.

[11] Sprotles, G. B., \& Kendall, E. L. (1986). A methodology for profiling consumers' decision- making styles. Journal of Consumer Affairs, 20(2), 267-279

[12] Parasuraman, A., Zeithaml, V. A., \& Berry, L. L. (1988). Servqual: A multiple-item scale for measuring consumer perc. Journal of retailing, 64(1), 12.

[13] Santos, J. (2003). E-service quality: a model of virtual service quality dimensions. Managing Service Quality: An International Journal, 13(3), 233-246.

[14] Kyoon Yoo, D., \& Ah Park, J. (2007). Perceived service quality: Analyzing relationships among employees, customers, and financial performance. International Journal of Quality \& reliability management, 24(9), 908-926.

[15] Jahanshahi, A. A., Gashti, M. A. H., Mirdamadi, S. A., Nawaser, K., \& Khaksar, S. M. S. (2011). Study the effects of customer service and product quality on customer satisfaction and loyalty. International Journal of Humanities and Social Science, 1(7), 253-260.

[16] Tanksale, D., Neelam, N., \& Venkatachalam, R. (2014). Consumer decision making styles of young adult consumers in India. Procedia-Social and Behavioral Sciences, 133, 211-218.

[17] Sekaran, U. (2003). Research Method for Bussiness: A Skill Building Approach 4 th ed New York. In: John Willey and Son inc.

[18] Gonen, E., \& Osemete, E. (2006). Decision-making styles of young Turkish consumers. Journal of the Home Economics Institute of Australia, 13(1), 26-33.

[19] Smadi, Z., \& Al-Jawazneh, B. E. (2011). The Consumer Decision Making Styles of Mobile Phones among the University Level Students in Jordan. International Bulletin of Business Administration, 10, 104-121.
[20] Cleaver, J. Y. (1985). Brand names rattle retail shelves. Advertising Age, 14, 28-29.

\section{AUTHORS PROFILE}

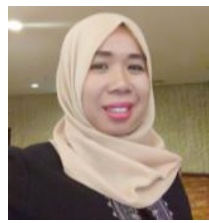

Realize Doctor of economics by concentrating in marketing. Currently she is a lecturer and as chairman of the quality assurance center at Putera Batam University, Batam - Kepulauan Riau, Indonesia. She can be reached through realize.eel@gmail.com or realize@puterabatam.ac.id.

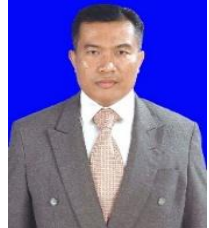

Tukino. Master of Information System Management, STMIK Putera Batam, Certified Cisco CCNA Instructor, Electrical Engineering and Information Technolgy Dept. Gadjah Mada University 2016, Lecturer of Computer Science Department of Putera Batam University, Batam - Kepulauan Riau, Indonesia. Email: tukino@puterabatam.ac.id.

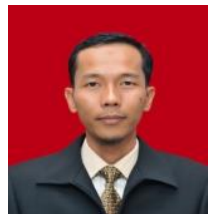

Emil Eka Putra Master of Arts concentrating on Contemporary Literature. He is currently a lecturer of English Department of Putera Batam University, Batam - Kepulauan Riau, Indonesia. He can be reached through emil.eka@puterabatam.ac.id. 